\title{
Onychomadesis following Gianotti-Crosti Syndrome
}

\author{
Damevska Katerina $^{1 *}$, Oncheva Radmila ${ }^{2}$, Oncheva Silvana ${ }^{3}$ and Duma Silvia ${ }^{1}$ \\ ${ }^{1}$ Clinic of Dermatology, Medical Faculty, University “SsCyrilius and Methodius”, Skopje, Republic of Macedonia \\ ${ }^{2}$ PHIZeleznichar, Skopje, Republic of Macedonia \\ ${ }^{3}$ Institute of Public Health, Skopje, Republic of Macedonia
}

\begin{abstract}
Onychomadesis is asymptomatic separation of the nail plate from the nail matrix, beginning at its proximal end, possibly due to a temporary nail matrix arrest. Here we describe a 13-month-old girl with onychomadesis on her hands, following Gianotti-Crosti syndrome.
\end{abstract}

\section{Introduction}

Beau's lines and onychomadesis fall along a spectrum of nail dystrophies that occur secondary to nail matrix arrest (NMA). Beau's lines are transverse, band-like depressions extending from one lateral edge of the nail to the other [1]. Onychomadesis is considered an extreme form of Beau's line with subsequent separation of the proximal nail plate from the nail bed [2].

Conditions that can cause NMA include: infections, severe systemic diseases, nutritional deficiencies, trauma, periungual dermatitis, chemotherapy, fever, and drug ingestion [2].

Here we describe a 13-month-old girl with onychomadesis on her hands, following Gianotti-Crosti syndrome.

\section{Case report}

A13-month-old girl was referred for evaluation of a rash that had been present for five days. Past history revealed an episode of watery diarrhea and fever, treated symptomatically, two weeks before the onset of the skin lesions. The rash had begun on the cheeks and upper extremities and spread to affect the lower extremities.

Examination revealed an otherwise healthy, active child. Multiple erythematous papules were note on her face, and on both upper and lower extremities (Figure 1). Several papulovesicles were also present

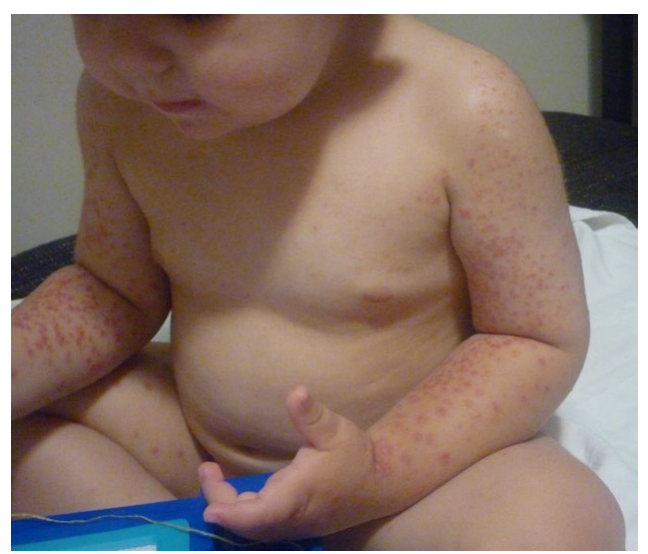

Figure 1: on her gluteal region (Figure 2). There were no lesions on the palms and soles. No hepatosplenomegaly or lymphadenopathy was detected.

A diagnosis of Gianotti-Crosti syndrome was made and a causative role of a gastrointestinal viral infection was suggested. Routine hematology and serum chemistry revealed no abnormalities. Serology tests for hepatitis $\mathrm{A}, \mathrm{B}$, and $\mathrm{C}$ virus were negative. We did not perform additional bacteriological and virological tests. A complete regression of the skin lesions was seen after 6 weeks, during the regression of the skin rush, changes on her fingernails were noted.

The mother denied any recent trauma, unusual activities or drug exposure.

Upon examination, painless, palpable grooves were noted on the nails, on the middle and index finger of the right hand (Figure 3), as well as the thumb, middle and ring finger of her left hand (Figure 4).

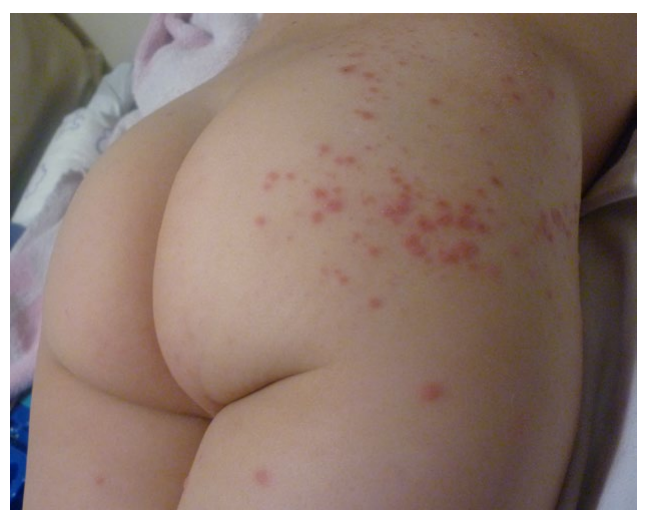

Figure 2:

Correspondence to: MKaterina Damevska, Clinic of Dermatology, Medical Faculty, University "Ss Cyril and Methodius", Skopje, Republic of Macedonia, E-mail: kate_damevska@yahoo.com

Key words: Gianotti-Crosti syndrome, nail maitrix arrest, Beau's lines, onychomadesis, proximal nail shedding

Received: January 18, 2016; Accepted: February 01, 2016; Published: February 05,2016 


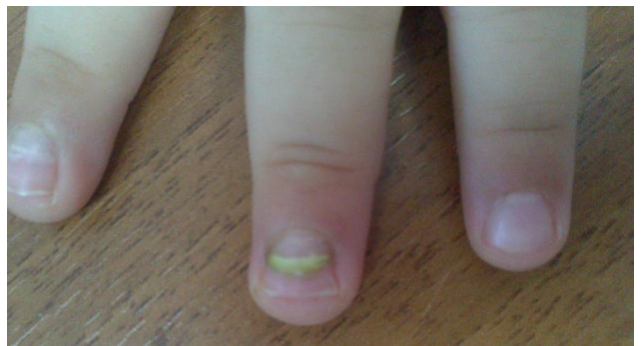

Figure 3:

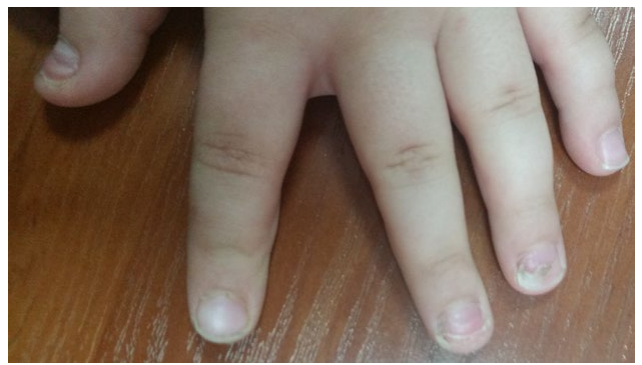

Figure 4:

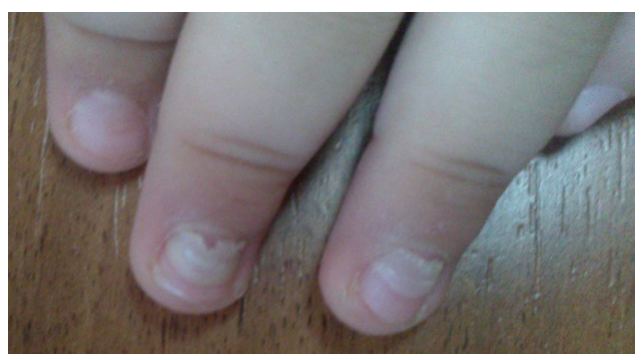

Figure 5:

The grooves were 2 to $3 \mathrm{~mm}$ in width, and were at a similar distance from the proximal nail fold. There were no signs of periungual inflammation. Potassium hydroxide preparationwas negative. A diagnosis of onychomadesis following GCS was made. During the follow up, two fingernails developed complete nail shedding (Figure 5). A spontaneous complete healing of the nailswas observed after 2 months.

\section{Discussion}

Gianotti-Crosti syndrome (GCS), or popular acrodermatitis of childhood is a distinctive self-limiting rash with a characteristic acrally distributed papulovesicular eruption. GCS is considered a cutaneous response to various immunologic triggers. The original cases, described by Gianotti in 1955, were associated with hepatitis B virus infection, but other viruses such as EBV, CMV, coxsackievirus, hepatitis A virus, parainfluenza virus, respiratory syncytial virus, rotavirus, mumps, parvovirus and molluscumcontagiosum have been reported to be associated with GCS [3]. Bacterial infections, as well as immunizations [4], have also been implied in the etiology of this condition.
Beau's lines and onychomadesis show strong associations with viral infections in childhood. Hand, foot and mouth disease (HFMD), followed by onychomadesis was first reported in 2000 in 5 children in Chicago [5]. Isolated onychomadesis cases following HFMD have been described in the France [6], Spain [7] and also Finland [8]. More recently, varicella related cases have been observed $[9,10]$.

It is unclear whether the NMA resulted from an inflammation spreading from skin lesions around the nails, or whether a viral infection had severe systemic impact on the general condition of the children. The detection of Coxackie virus in the shedded nail particle, following HFMD, suggests that the viral replication itself may directly damage the nail matrix [11].

In the present case, acute diarrhea and fever preceded GCS for 2 weeks, and onychomadesis for 5 weeks. Both can be considered as late manifestations of a viral gastrointestinal infection.

Although there was a suspicion of viral etiology of GCS and onychomadesis, we did not perform serological tests because the patient would not have any additional benefit from them. Nevertheless, an etiologic diagnosis may only be reached in less than half of the patients, even using a large range of microbiological investigations [12,13].

GCS and onychomadesis remains an enigmatic reaction to different agents, and both conditions can be regarded as a rare and late complication of a viral infection in young children.

\section{References}

1. De Barber D (1996) What do Beau's lines mean. Int J Dermatol 134: 542-547.

2. Hardin J, Haber RM (2015) Onychomadesis: literature review. Br J Dermatol 172: 592-596. [Crossref]

3. Caputo R, Gelmetti C, Ermacora E, Gianni E, Silvestri A (1992) Gianotti-Crost syndrome: a retrospective analysis of 308 cases. $J$ Am Acad Dermatol 26: 207-210. [Crossref]

4. Atanasovski M, Dele-Michael A, Dasgeb B, Ganger L, Mehregan D (2011) A case report of Gianotti-Crosti post vaccination with MMR and dTaP. Int J Dermatol 50: 609-610. [Crossref]

5. Clementz GC, Mancini AJ (2000) Nail matrix arrest following hand-foot-mouth disease: a report of five children. Pediatr Dermatol 17: 7-11. [Crossref]

6. Bernier V, Labrèze C, Bury F, Taïeb A (2001) Nail matrix arrest in the course of hand foot and mouth disease. Eur J Pediatr 160: 649-651. [Crossref]

7. Redondo Granado MJ, Torres Hinojal MC, Izquierdo López B (2009) [Post viral onychomadesis outbreak in Valladolid]. An Pediatr (Barc) 71: 436-439. [Crossref]

8. Osterback R, Vuorinen T, Linna M, Susi P, Hyypiä T, et al. (2009) Coxsackievirus A6 and hand, foot, and mouth disease, Finland. Emerg Infect Dis 15: 1485-1488. [Crossref]

9. Kocak AY, Koçak O (2013) Onychomadesis in two sisters induced by varicella infection. Pediatr Dermatol 30: e108-109. [Crossref]

10. Podder I, Das A, Gharami RC1 (2015) Onychomadesis Following Varicella Infection Is it a Mere Co-incidence? Indian J Dermatol 60: 626-627. [Crossref]

11. Bettoli V, Zauli S, Toni G, Virgili A (2013) Onychomadesis following hand, foot, and mouth disease: a case report from Italy and review of the literature. Int J Dermatol 52: 728-730. [Crossref]

12. Taïeb A, Plantin P, Du Pasquier P, Guillet G, Maleville J (1986) Gianotti-Crosti syndrome: a study of 26 cases. Br J Dermatol 115: 49-59. [Crossref]

13. Ricci G, Patrizi A, Neri I, Specchia F, Tosti G, et al. (2003) Gianotti-Crosti syndrome and allergic background. Acta Derm Venereol 83: 202-205. [Crossref]

Copyright: $@ 2016$ Katerina D. This is an open-access article distributed under the terms of the Creative Commons Attribution License, which permits unrestricted use, distribution, and reproduction in any medium, provided the original author and source are credited. 